\title{
HUMANISME PENDIDIKAN: KRITIK TERHADAP MATERI SEJARAH KEBUDAYAAN ISLAM DI MTS
}

\author{
Khamim Saifuddin \\ khamimsay@yahoo.com \\ Sekolah Tinggi Agama Islam Nahdlatul Ulama (STAINU) Temanggung \\ Hamidulloh Ibda \\ h.ibdaganteng@stainutmg.ac.id \\ Sekolah Tinggi Agama Islam Nahdlatul Ulama (STAINU) Temanggung
}

DOI:10.21580/wa.v6i2.5731

\begin{abstract}
Nowadays, the climate of social life in society is experiencing civilization shocks. All cannot be separated from the education given. The Islamic Cultural History subject as a compulsory subject greatly contributes to the formation of children's thinking patterns in the future. This paper intends to provide a discourse critique of the material by using the perspective of the concept of educational humanism. In this article, a descriptive qualitative approach feels appropriate to use to see the object under study, while the data collection method comes from the research library. Specifically, for material at the MTs level, the author sees some irregularities about this material. Taking material too puts forward the problem of violence which has an impact on intolerance, although it cannot be denied that this has actually happened in the course of history. Gender equality, the spirit of liberation and child psychology are not given in a balanced way, so there is a stigma that this material is not proportional and only provides an understanding of the spirit of oppression and defeat.
\end{abstract}

Keywords: Educational Humanism, Islamic Cultural History, MTS

\begin{abstract}
Abstrak
Dewasa ini iklim kehidupan sosial masyarakat mengalami goncangan peradaban. Semua tidak bisa dilepaskan dengan pendidikan yang diberikan.
\end{abstract}


82 Humanisme Pendidikan .....

Mata pelajaran Sejarah Kebudayaan Islam sebagai salah satu mata pelajaran wajib sangat berkontribusi mewarnai pembentukan pola fikir anak ke depan. Tulisan ini bermaksud memberikan kritik wacana terhadap materi tersebut dengan menggunakan sudut pandang konsep humanisme pendidikan. Dalam artikel ini pendekatan kualitatif deskriptif di rasa tepat digunakan melihat obyek yang diteliti, sedangkan metode pengambilan datanya bersumber dari library research. Khusus materi di tingkat MTs, penulis melihat ada beberapa kejanggalan tentang materi tersebut. Pengambilan materi terlalu mengedepankan masalah kekerasan yang berimbas pada intoleransi meski tidak bisa dimungkiri hal tersebut benar-benar terjadi dalam perjalanan sejarah. Kesetaraan gender, semangat pembebasan dan psikologi anak kurang diberikan secara berimbang sehingga muncul sebuah stigma bahwa materi ini kurang proporsional dan hanya memberikan pemahaman tentang semangat menindas dan mengalahkan.

Kata Kunci: Humanisme Pendidikan, Sejarah Kebudayaan Islam, MTs

\section{A. Pendahuluan}

Kehidupan sosial, agama dan budaya selalu mengalami perkembangan bersama dalam sisi kehidupan manusia. Perkembangan ilmu pengetahuan dan teknologi mampu menghasilkan sebuah keseimbangan kehidupan. Peran pendidikan diharapkan menghasilkan produk yang memiliki nilai ekonomis dan budaya. Pada akhirnya akan mampu mengatasi keterbelakangan peradaban manusia.

Manusia mempunyai fungsi utama sebagai aktor utama dalam percaturan global. Mempertahankan hidup di dunia dengan baik menjadi suatu visi besar yang sangat diharapkan. Untuk itulah kemudian semangat bertahan hidup dengan segala pernakperniknya menjadi tujuan filosofis pendidikan.

Ada beberapa poin usaha guna memenuhi kebutuhan dasar manusia. Kebutuhan yang berhubungan dengan ruhiyah (kepuasaan batin) maupun jasadiyah (kepuasaan lahir). Kebutuhan ini tidak akan terpenuhi jika peran pendidikan sebagai instrumen utama tidak dapat di tata secara baik. Melihat peran pendidikan terhadap kebudayaan begitu besar, tidak mengherankan jika ada yang berpendapat bahwa pendidikan merupakan bagian pokok (otak) dari perkembangan budaya. Dinamika kehidupan manusia selalu berhubungan dengan pendidikan pada akhirnya tergambar dalam perilaku baik keagamaan maupun kebudayaan.

Selanjutnya dapat dikatakan bahwa pendidikan merupakan sarana pembentuk budaya dalam peradaban. Dalam pendapat John Dewey, dinyatakan bahwa pendidikan sebagai alat tranformasi budaya. ${ }^{1}$ Aspek nilai normatif dalam penyusunan konsepnya menjadi cirri khas ilmu sosial humaniora.

\footnotetext{
${ }^{1}$ Sembodo Ardi Widodo, Kajian Filosofis Pendidikan Barat dan Islam (Jakarta: Nimas Multima,
} 2003), 26. 
Kehidupann beragama sangat ditentukan oleh seberapa banyak seseorang mendapatkan pendidikan. Tuntunan umat manusia dalam bentuk mushaf itu tidak serta merta dapat dipahami tanpa adanya ilmu dan pendidikan, sehingga maksud dan tujuannya dapat direalisasikan dengan benar. Penafsiran-penafsirannya ayat pasti akan mengacu pada perkembangan zaman, maka penafsiran nash Al Qur'an adalah sesuatu yang relatif, karena selalu berhubungan dengan ruang, waktu, tempat dan konteks serta tingkat ketinggian ilmu yang berbeda. ${ }^{2}$ Dari hal ini membuktikan bahwa posisi Al Qura'an sangat sesuai dengan perkembangan zaman.

Sebagai makhluk individu sekaligus makhluk sosial, manusia harus mempunyai konsep yang benar-benar bisa membawa manusia pada tujuan utama kehidupan manusia baik sebagai pemimpin di muka bumi (kholifah fil ardl) maupun dalam melaksanakan janji primordial kepada Tuhan berupa ibadah ${ }^{3}$. Melalui pendidikan, bimbingan kepada peserta didik untuk mencapai kedewasaan menjadi kewajiban asasi manusia lainnya. Pada akhirnya mampu bertanggung jawab atas perbuatannya sebagai pengembang individu.

Pendidikan menurut Islam adalah suatu proses penyiapan anak-anak sebagai sumber daya manusia yang di kemudian hari dapat melakukan pekerjaannya dalam bidang keduniawian dan ukhrowi. Artinya bahwa pendidikan merupakan wahana bagi anak (manusia yang sedang berkembang) dalam mengembangkan diri sebagai personal yang unik. Karena peran inilah kurikulum pendidikan harus menuangkan materi-materi yang membangun dan berpijak pada kepentingan-kepentingan anak. Secara substansi pendidikan, penerapan kurikulum mempunyai dampak bagi kehidupan baik dampak positif maupun negative. ${ }^{4}$ Dalam Islam dampak negatif pendidikan dapat dihilangkan dengan meletakkan akhlak pada posisi yang vital dan fundamental. ${ }^{5}$.

Menurut pandangan Al Jundi bahwa yang menjadi ukuran kebaikan dan kebahagian hidup sebagai implemetasi akhlak adalah keimanan dan ketaqwaan. Hal ini dapat dipahami dari firman Allah dalam surat An-Nahl 97 "Barang siapa beramal soleh baik laki-laki atau perempuan, sedangkan ia beriman, Kami akan hidupkan ia dengan kehidupan yang baik, dan Kami balas pahalanya setimpal dengan apa yang ia perbuat" ${ }^{6}$.

Akhlak yang diterapkan pendidikan Islam berperan pada wilayah kemanusiaan yaitu pada hubungan manusia dengan manusia dan manusia dengan Allah. Oleh karena itu akhlak mempunyai nilai absolut yang tidak dapat dipisahkan dengan kata lain bahwa antara hubungan manusia kepada manusia dan manusia kepada Tuhan tidak dapat dipisahkan dan keduanya saling berhubungan.

Sebagai salah satu lembaga pendidikan Islam, madrasah memberikan materi sejarah kebudayaan Islam pada posisi yang penting. Tujuan pemberian materi diantaranya mengenalkan tentang keberlangsungan sejarah kebudayaan Islam yang di mulai dari zaman Rasul hingga hari ini. Harapannya bisa menjadi teladan sehingga keimanan dan ketaqwaan akan bertambah pada diri peserta didik. Dalam konteks peningkatan kapasitas akhlak

\footnotetext{
${ }^{2}$ Nurjanah Ismail, Perempuan Dalam Pasungan (Yogyakarta: LKis, 2003), 2.

${ }^{3}$ Depag RI, Al Qur'an dan Terjemahannya (Bandung: Gema Risalah, 1992), 862.

${ }^{4}$ Chabib Toha, Reformulasi Filsafat Pendidikan Islam (Yogyakarta: Pustaka Pelajar, 1996), 65.

${ }^{5}$ Ardi Widodo, Kajian Filosofis Pendidikan Barat dan Islam, 166.

${ }^{6}$ Depag RI, Al Qur'an dan Terjemahannya, 417.
} 
$84 \mid$ Humanisme Pendidikan .....

peserta didik bisa I'tiba kepada para pendahulu Islam. Siswa tak akan dapat menghayati atau bahkan akan cenderung meremehkan kepada sesuatu ketika tidak tahu akan asal-usul sejarah tersebut.

Dalam praktik pendidikan fenamena perbedaan membuat ketidaknyamanan dalam belajar. Sesungguhnya dikotomi pendidikan seperti ini tidak menjadi sebuah permasalahan, namun harus dijadikan sebuah energi baru. Prinsip dasarnya keduanya mempunyai tugas kemanusiaan yang sama sebagaimana Allah telah berfirman dalam surat Al An'am ayat 165 yaitu: "Dan Allah yang menjadikan kamu penguasa-penguasa di bumi dan Dia meninggikan sebagian (yang lain) beberapa derajat, untuk mengujimu tentang apa yang diberikan-Nya kepadamu. Sesungguhnya Tuhanmu amat cepat siksa-Nya dan sesungguhnya Dia Maha Pengampun lagi Maha Penyayang."”

Pendidikan adalah unsur terbesar dari sebuah pembentukan pola pikir peserta didik yang nantinya akan menjadi manusia dewasa yang akan menjalankan tugas kemanusiaannya sehingga sebuah budaya dan kehidupan beragama akan terpancar dari realisasi pendidikan. Jadi semua manusia berhak untuk mendapatkan berbagai macam materi pelajaran tanpa adanya pembedaan materi. Hal inilah yang dituntut untuk selalu menerapkan praktik-praktik human oriented atau dengan kata lain memanusiakan manusia itu sendiri.

Dengan upaya pemanusiaan pendidikan tersebut berarti upaya pelestarian nilai-nilai insani yang akan menuntun jalan kehidupan dan keberadaannya secara individual maupun sosial adalah salah satu fungsi pendidikan menurut kajian antropologi dan sosiologi, akan berjalan dengan baik dan benar ${ }^{8}$.

Melihat realitas pendidikan tersebut, penulisakan menganalisis ulang tentang penerapan materi sejarah kebudayaan Islam dengan menggunakan perpektif humanisme pendidikan dalam artikel ini. Untuk dapat mensistematiskan arah pembuatan artikel ini, penulis membuat batasan-batasan pembahasan yang jelas. Adapun fokus dari artikel ini penulis lebih menitik beratkan pada analisis psikologi perkembangan anak.

Bertolak dari latar belakang di atas muncul pertanyaan mendasar yang akan dijadikan pijakan utama dalam penulisan artikel ini. Pertama, apakah dalam materi sejarah kebudayaan Islam di MTs terdapat konsep humanisme pendidikan? kedua, bagaimanakah konsep materi sejarah kebudayaan Islam yang ideal sesuai dengan konsep humanisme pendidikan?

\section{B. Metodologi penelitian}

Dalam artikel ini penulis mengambil data dari berbagai sumber buku yang berhubungan dengan pendidikan. Selanjutnya teknik ini disebut dengan teknik library reseach (study kepustakaan). ${ }^{9}$ Sedangkan jenis penelitian yang digunakan adalah penelitian

\footnotetext{
${ }^{7}$ Depag RI, 165.

${ }^{8}$ Kusti'ah dan Anny Aisah, Belajar Gender Analisis Mengurai Ketimpangan Gender dalam Realitas Masyarakat (Semarang: JGJ PMII Jateng, 2005), 46.

${ }^{9}$ Lexy J. Moleong, Metodologi Penelitian Kualitatif(Bandung: Remaja Rosda Karya, 2007), 26.
} 
kualitatif-deskriptif. ${ }^{10}$ Penulis membagi data menjadi 2 sumber data yaitu data primer dan data skunder. Data primer mengambil dari buku Kurikulum Madrasah Tsanawiyah (Standar Kompetensi) yang disusun oleh Departemen Agama RI dan diterbitkan oleh Departemen Pendidikan Nasional dan Buku materi ajar sejarah kebudayaan Islam Kurikulum 2004 Berbasis Kompetensi Madrasah Tsanawiyah Kelas 1,2,dan 3 yang disusun oleh Drs Murodi, MA dan diterbitkan oleh PT Karya Toha Putra Semarang, Sedangkan untuk data sekunder penulis mengambil dari buku pendidikan dan buku yang berbicara tentang masalah psikologi anak.

Sejalan dengan jenis penelitian maka penulis mengumpulkan data dengan melakukan pembacaan dan pencermatan serta penelitian terhadap buku-buku primer. Teknik analisis data dengan metode refleksi terhadap pendidikan penyusun menganalisis data dan informasi dengan melakukan hal-hal sbb; membaca dan menelaah seluruh data yang terkumpul, mengadakan proses reduksi dan kemudian merangkum dalam kata-kata sendiri, dan terakhir memadukan data yang ada dalam bentuk deskriptif argumentatif.

Selanjutnya penulis menfokuskan pada penentuan tentang tujuan, pengalaman, dan aktivitas pendidikan yang mengarah pada bentuk keadilan, persamaan, dan kepuasan. Dalam hal pemenuhan kebutuhan dasar manusia ini oleh Spark Langer mengistilahkan ke dalam narasi refleksi kritis. ${ }^{11}$

\section{Pembahasan}

\section{Humanisme Pendidikan}

Humanisme pendidikan berasal dari akar kata humanisme dan pendidikan, humanisme berarti sebuah ajaran yang menekankan pada sisi kemanusiaan. Sedangkan pendidikan mempunyai arti proses yang memungkinkan untuk melakukan proses pengkayaan budaya non fisik (memelihara dan mengembangkan) dalam mengasuh dan mendidik anak-anak ataupun orang dewasa ${ }^{12}$.

Dari penggabungan dua kata tersebut dapat kita definisikan bahwa konsep humanisme pendidikan berarti proses pengkayaan budaya manusia yang bersifat non fisik dengan menggunakan ajaran yang mengusung isu-isu kemanusiaan sebagai konsentrasi utamanya. ${ }^{13}$

Konsep humanisme pendidikan memiliki ciri khas yang bertujuan menciptakan peradaban umat manusia tanpa adanya embel-embel kekerasan dan penindasan. Secara sederhana teori dasar humanisme pendidikan adalah Pertama, semangat pembebasan yang merupakan karakteristik alamiah yang dimiliki oleh manusia. Berawal dari karakteristik ini menjadikan manusia setingkat menjadi maju dibanding makhluk lainnya. Kebebasan untuk berekspresi dan menentukan arah pendidikannya sendiri menjadi hak prerogratif peserta

\footnotetext{
${ }^{10}$ Suharsimi Arikunto, Prosedur Penelitian Suatu Pendekatan Praktek (Jakarta: Rineke Cipta, 2002),
} 11.

11 Toha, Reformulasi Filsafat Pendidikan Islam, 234.

12 Pius A Partanto dan M Dahlan Al Barry, Kamus Ilmiah Populer (Surabaya: Arkola, 1994), 247.

${ }^{13}$ Ardi Widodo, Kajian Filosofis Pendidikan Barat dan Islam, 15. 
didik. Memilih kehidupan masa depannya tanpa adanya sebuah pemaksaan bahwa kamu harus jadi ini dan kamu harus jadi itu secara implicit menjadi target esensial setiap manusia. 14

Dalam ranah pembebasan ini tentunya lembaga pendidikan perlu memberikan konsepsi materi yang memiliki kesinambungan antara keinginan peserta didik. Keberadaan kurikulum pendidikan harus bisa mewadahi semua karakter masing-masing siswa yang ada. Selama ini kita bisa melihat bahwa masih terjadi banyak ketimpangan materi yang disampaikan dalam berbagai materi ajar, baik berupa materi dalam bentuk gambar maupun dalam bentuk tulisan.

Menurut konsep humanisme pendidikan penindasan, ketertinggalan dan kebodohan manusia di mulai dari kesalahan penerapan sistem pendidikan yang masih bersifat eksklusif. Untuk itu konsep humanisme pendidikan tetap konsen pada isu-isu kemanusiaan yang bersifat inklusif agar wacana ini benar-benar dapat terwujud dalam lingkup pendidikan. ${ }^{15}$

Berdasarkan teori pembebasan pembentukan karakter masing-masing manusia dimulai dari kebebasan berfikir kritis terhadap realitas wacana yang berkembang. Tak bisa kita nafikan bahwa dorongan dari luar sangat berpengaruh dalam perkembangan psikologi manusia sehingga proses pencitraan diri seseorang yang merupakan ending dari persoalan krusial dalam konteks kekinian menjadi terhambat akibat kesalahan kurikulum pendidikan. Penerapan kurikulum yang masih sarat dengan kepentingan politis, beberapa buku rujukan masih mengedepankan upaya pembunuhan karakter terhadap beberapa sosok dan juga tokoh-tokoh yang tertuang dalam materi.

Inilah yang dimaksud dengan teori pembebasan ala konsep humanisme pendidikan. Seorang peserta didik membutuhkan sebuah perlakuan yang layak sesuai dengan kodrat mereka sebagai manusia. Lebih tegas lagi bahwa pendidikan harus bersifat netral dan tidak ada nuansa-nuansa penggiringan terhadap suatu opini yang berkembang sejalan dengan perkembangan peradaban umat manusia seperti temuan beberapa penelitian yang masih sarat dengan nilai-nilai kekerasan, peminggiran seksis, fundamentalime dan juga nuansanuansa politik-politik pendidikan lainnya.

Kedua, Kebersamaan (sensitive gender). Kesatuan manusia tidak akan tergapai ketika relasi dan komunikasi tidak diciptakan dengan massif. Bisa kita ambil contoh, proses penciptaan awal Adam dan Hawa tak terlepas dari sebuah peranan komunikasi, juga ketika keduanya diturunkan dari surga ke bumi juga tidak luput dari komunikasi. Melihat tujuan awal dari penciptaan tersebut menjadi keuntungan bagi manusia untuk memperlakukan orang lain sesuai dengan posisi strategisnya bukan sebaliknya menggunakan pandangan tentang proses pembuangan umat manusia ke bumi karena bujukan Hawa untuk memakan buah haram (khuldi). ${ }^{16}$

\footnotetext{
${ }_{14}$ Paulo Freire, Poltik Pendidikan (Yogyakarta: Pustaka Pelajar, 2002), 22.

15 Freire, 27.

16 Elis Sarifatun, "Pendidikan Androgene; Sebuah Refleksi Terhadap Materi Pelajaran,
} Temanggung," 2005, 33. 
Realitas di lapangan sering kita jumpai praktik pengagungan pribadi. Nuansa keakuan ini menjadi polemik yang memarginalkan orang lain dalam berbagai sisi termasuk dalam kancah pendidikan. Ironisnya praktik pengakuan ini dilandasi dengan perbedaan jenis kelamin yang seharusnya menjadi pemersatuan umat manusia. Membuminya budaya patriarkhi dalam masyarakat memunculkan kesan adanya pengkotak-kotakan peran makhluk, laki-laki adalah makhluk superior (high class) dan perempuan adalah makhluk nomor dua (second class). Pemisahan kelas sosial ini tentunya menjadi sebuah pertanyaan besar, bagaimana pemisahan kelas ini bisa terbentuk sedangkan anggapan semacam ini masih menjadi sebuah tradisi yang abadi. ${ }^{17}$

Pengembangan wacana gender sebagai bagian kritik sosial terhadap sebuah konstruksi budaya, ternyata tidak serta merta dapat direspon dengan baik oleh kalangan laki-laki bahkan juga oleh perempuan sendiri. Berbagai alasan lahir secara massif untuk melawan atas semaraknya analisis-analisis tentang isu seksis, rasis dan diantaranya menggagas kesetaraan gender berarti mempersoalkan system dan struktur yang sudah mapan dengan kata lain bahwa dengan menganalisis gender maka akan menggoncangkan system status quo ketidakadilan tertua dalam sejarah peradaban masyarakat. ${ }^{18}$

Ketika pembahasan gender dengan tidak disertai dengan pengertian yang memadai apa sebenarnya itu gender dan bagaimana sebenarnya tujuan dari pemunculan isu gender, maka kontruksi budaya tidak akan berjalan dengan maksimal. Analisa gender bagi kaum awam akan mensinonimkan dengan persoalan perempuan namun sebenarnya ada korelasi laki-laki dan perempuan yang tak akan bisa dilepaskan. Disadari ataupun tidak kedua jenis kelamin ini merupakan relasi kuat yang memiliki persamaan, kesetaraan dan hak dalam percaturan global.

Adanya perbedaan gender yang melekat pada manusia tidak akan menjadi sebuah persoalan jika tidak melahirkan ketidakadilan kelas, namun realitas yang ada, dengan keberadaan gender memunculkan sebuah ketidakadilan jenis kelamin tertentu. Menurut Mansour Fakih bahwa adanya perbedaan gender melahirkan ketidakadilan pada jenis kelamin tertentu. ${ }^{19}$

Marginalisasi merupakan salah satu manifestasi dari adanya bias gender dimana adanya perbedaan gender mengakibatkan terpinggirkan atau pemiskinan salah satu jenis kelamin dalam hal ini adalah perempuan. ${ }^{20}$ Mekanisme marginalisasi akibat dari perbedaan terbentuk dari berbagai proses maupun sesuatu yang melatar belakanginya misalnya kebijakan pemerintah, keyakinan, tafsiran agama, keyakinan tradisi, dan kebiasaan atau bahkan asumsi ilmu pengetahuan. Contoh kongkrit dengan adanya program pemerintah tentang revolusi hijau secara ekonomi telah memiskinkan perempuan karena ani-ani sebagai alat pertanian perempuan ditiadakan untuk program revolusi hijau tersebut.

Kesadaran yang tidak sensitive gender dapat menimbulkan subordinasi, sterotipe, kekerasan (violence), beban ganda (double burden) semakin merajalela di tengah

\footnotetext{
${ }^{17}$ Mansur Fakih, Analisis Gender \& Transformasi Sosial (Yogyakarta: Pustaka Pelajar, 2001), 5.

${ }^{18}$ Fakih, 17.

${ }^{19}$ Fakih, Analisis Gender \& Transformasi Sosial, 15.

${ }^{20}$ Fakih, 15.
} 
masyarakat. $^{21}$ Menggagas wacana gender tidaklah begitu mudah, ada anggapan membongkar masalah gender berarti melawan sebuah kultur. Anggapan masyarakat bahwa masalah gender sudah mapan dan sudah dianggap kodrat, sehingga membicarakan gender telah dianggap melawan kehendak Tuhan.

Penafsiran agama yang tidak sensitive gender merupakan bagian yang menkonstruk adanya ketidakadilan gender, untuk itu diperlukan penafsiran ulang terhadap materi-materi dalam dunia pendidikan yang masih bias gender. Karena bagaimanapun juga setiap pendidikan datang membawa misi utama yaitu menegakkan keadilan. Seperti halnya pendidikan agama Islam, yang banyak dianggap agama yang menyebabkan adanya ketidakadilan gender dengan tafsiran ayat-ayatnya yang masih bias.

Namun ketika dicermati dengan betul, sebenarnya pendidikan Islamlah yang pertama kali memunculkan kesetaraan antara laki-laki dan perempuan. Hal ini bisa kita lihat kembali ketika Islam datang di bumi suci ketika jaman Jahiliyah yang waktu itu masyarakatnya menganggap bahwa anak perempuan tidak ada harganya sama sekali. ${ }^{22}$ Dikuburkanya bayi-bayi perempuan yang masih hidup merupakan kebanggaan tersendiri karena dengan menguburnya kehormatan sebuah keluarga akan pulih kembali.

Dengan argumentasi ini dapat membuka tabir yang selama ini Islam dianggap agama yang turut melanggengkan ketidakadilan gender dan Islam juga bukanlah agama penindas kaum perempuan seperti anggapan yang selama ini kita dengar. Inilah mengapa konsep humanisme pendidikan menempatkan teori kebersamaan menjadi salah satu harga mati untuk diterapkan dalam dunia pendidikan. ${ }^{23}$

\section{Sejarah Kebudayaan Islam di MTs}

Kehidupan dan peradaban senantiasa mengalami perubahan, untuk merespon hal itu dunia pendidikan khususnya lembaga pendidikan harus selalu melakukan penyempurnaan kurikulum, agar kualitas pendidikan mampu menciptakan kehidupan yang cerdas, damai, terbuka, demokratis, dan mampu bersaing.

Sejarah kebudayaan Islam di Madrasah Tsanawiyah bukan satu-satunya faktor pembentuk watak dan kepribadian peserta didik. Tetapi secara substansial pelajaran Sejarah Kebudayaan Islam memiliki kontribusi yang cukup besar dalam memberikan motivasi keberagamaan kepada peserta didik. Di samping itu materi Sejarah kebudayaan Islam dijadikan sebagai barometer terkuat dalam mempraktikan nilai-nilai keyakinan ketuhanan (tauhid) dan akhlakul karimah dalam kehidupan sehari-hari.

Dalam juklak Kurikulum Madrasah Tsanawiyah (Standar kompetensi) yang dikeluarkan atas kerjasama Departemen Agama Republik Indonesia dan Departemen Pendidikan Nasional 2004 telah dipaparkan dengan jelas tentang pengertian umum, tujuan materi dan ruang lingkup materi sejarah kebudayaan Islam serta sudah dilakukan proses

${ }^{21}$ Fakih, 21.

${ }^{22}$ A Syalabi, Sejarah dan Kebudayaan Islam (Jakarta: Pustaka Alhusna, 1990), 72.

${ }^{23}$ Achmad Muthali'in, Bias Gender dalam Pendidikan (Surakarta: Muhammadiyah University Perss, 2001), 44 . 
standarisasi kompetensi bahan kajian, sesuai kondisi keberagamaan peserta didik seluruh Indonesia. ${ }^{24}$

Sejarah kebudayaan Islam adalah salah satu mata pelajaran yang mempelajari tentang peradaban khususnya tentang perkembangan agama Islam di dunia. Dalam materi ini siswa diarahkah untuk bisa mengenal, memahami, menghayati dan mengamalkan apa yang telah dilakukan oleh para pejuang Islam mulai dari zaman Rasulallah sampai dengan hari ini. Upaya ini tak akan terealisasi tanpa adanya bimbingan, pengajaran, latihan, penggunaan pengalaman dan pembiasaan. ${ }^{25}$

Kiranya dari pengertian di atas kita bisa mengambil satu hal yang menarik dalam kaitannya dengan kehidupan berbangsa, bernegara dan beragama. Dalam konteks bernegara siswa dituntut untuk bisa berperan sebagai warga negara yang baik dan selalu menanamkan sebuah gagasan yang cerdas demi kemajuan negaranya. Disamping itu para peserta didik dituntut untuk bisa berbaur dengan masyarakat yang semua beragam baik dari suku, ras dan multi agama. Artinya perbedaan yang ada bukanlah sebuah sarana perpecahan namun sebaliknya dapat hidup berdampingan dengan masyarakat lainnya (ukhuwah wathoniyah, ukhuwah Islamiyah dan ukhuwah basyariyah).

Mata pelajaran sejarah kebudayaan Islam bertujuan untuk memberikan pengetahuan tentang sejarah Agama Islam dan kebudayaannya. Selain itu siswa dituntut untuk bisa mengambil teladan (ibrah), nilai dan makna yang terdapat pada sejarah kebudayaan Islam.

Menanamkan penghayatan dan kemauan yang kuat untuk mengamalkan nilai-nilai keIslaman secara kaffah dengan mengambil tauladan tokoh-tokoh para pejuang penegak agama Islam juga merupakan salah satu tujuan mempelajari materi ini. ${ }^{26}$

\section{Pokok-Pokok Kajian SKI}

Untuk menjawab berbagai persoalan globalisasi maka pendidikan harus secara massif melakukan berbagai terobosan agar tercipta anak didik yang sesuai dengan cita-cita bangsa. Kurikulum yang merupakan bagian penting dalam lembaga pendidikan sudah memulai perkembangannya melalui berbagai ranah diantaranya ketrampilan, pengetahuan dan sikap. Yang dalam kurikulum 2004 ini dinamakan kurikulum berbasis kompetensi. Kompetensi merupakan perpaduan antara pengetahuan, ketrampilan, sikap dan nilai yang direfleksikan dalam kebiasaan berperilaku. ${ }^{27}$

Materi sejarah kebudayaan Islam disusun menggunakan data-data tentang sejarah kebudayaan Islam yang telah diterbitkan terlebih dahulu oleh historiolog. Selain itu juga diharapkan agar mampu menjaga kemurnian Aqidah Islam memiliki keimanan yang kokoh yang dilandasi dengan dalil-dalil naqli, dalil aqli maupun wijdani serta menjadi pelaku

${ }^{24}$ Tim Penyusun, Kurikulum Madrasah Tsanawiyah (standar Kompetensi) (Jakarta: Departemen Pendidikan Nasional, 2004), 21.

${ }^{25}$ Penyusun, 23.

${ }^{26}$ Penyusun, 68.

27 Mulyasa, Kurikulum Berbasis Kompetensi, Konsep, Karakteristik Implementasi dan Inovasi (Bandung: Remaha Rosdakarya, 2004), 39. 
90 Humanisme Pendidikan .....

ajaran Islam yang loyal, komitmen dan penuh dedikasi baik untuk keluarga masyarakat bangsa dan agama. ${ }^{28}$

Materi sejarah kebudayaan Islam di MTs memuat beberapa bab yang merangkum sejarah kebudayaan Islam pada masa setelah Rasul dan khulafaurrasyidin hingga masa kekhalifahan abad pertengahan. Masa pemerintahan dinasti Umayah yang dimulai dari pemerintahan Muawiyah sampai dengan keruntuhan dinasti tersebut. Dalam bab ini pula selain disinggung tokoh Muawiyah secara person, juga di ceritakan kemajuan-kemajuan prestasi Islam dalam hal-hal yang lainnya, misalkan pada bidang politik, militer dan tentunya pada bidang pendidikan agama Islam itu sendiri. Tak ketinggalan khalifah pasca Muawiyah seperti khalifah Umar bin Abdul Azis juga menjadi pokok bahasan dlam materi sejarah kebudayaan Islam di MTs sehingga siswa diharapkan dapat meneladani tokohtokoh tersebut dalam kehidupan sehari-hari.

Bab selanjutnya mempelajari tentang perkembangan dinasti Abbasiyah beserta tokoh-tokoh kekhalifahan dinasti ini. Tak luput disampaikan pula tentang capaian-capaian kemajuan dalam beberapa bidang kehidupan. Faktor-faktor kemundurannyapun tak lepas dalam pokok bahasan materi ini. ${ }^{29}$

Pokok-pokok materi pelajaran sejarah kebudayaan Islam ini kemudian dijabarkan dalam buku-buku panduan mengajar kelas VII, VIII dan IX. Buku Kelas VII berisi Latar belakang terbentuknya dinasti Umayah, Biografi Muawiyah bin Abi Sufyan, Khalifah Abdul Malik bi Marwan, Khalifah Al Walid bin Abdul Malik, Khalifah Umar bin Abdul Azis, Khalifah Hisyam bin Abdul Malik, Kemajuan yang dicapai dinasti Umayah dalam bidang administrasi negara dan juga pada bidang politik dan militer. ${ }^{30}$

Buku Kelas VIII berisi Kemajuan dinasti Umayah dalam bidang ilmu agama, Keruntuhan dinasti Umayah, Terbentuknya dinasti Abasiyah, Khalifah Abu Ja'far Al Mansur, Khalifah Harun Al Rasyid, Khalifah Abdullah Al Makmun, Kemajuan dinasti Abasiyah dalam bidang sosial budaya, Kemajuan dinasti Abasiyah dalam bidang politik dan militer. $^{31}$

Buku Kelas IX berisi Kemajuan dinasti Abasiyah dalam bidang pendidikan dan keilmuan, Keruntuhan dinasti Abasiyah, Terbentuknya dinasti Ayyubiyah dan tokoh khalifahnya serta perjuangan dalam memerangi kaum salibis di Yerusalem. ${ }^{32}$ Data-data yang penulis ambil berdasarkan dari buku sejarah kebudayaan Islam MTs kurikulum 2004 karya Drs. Murodi, terbitan PT Karya Toha Putra Semarang.

Hasil dari pengamatan awal dalam materi sejarah kebudayaan Islam terdapat tiga puluh tiga gambar yang menjadi ilustrasi dari sejarah kebudayaan Islam dan dari ke tiga puluh tiga gambar tadi menuangkan gambar-gambar bangunan peninggalan dinasti-dinasti tersebut dan juga situasi peperangan serta tokoh-tokoh pada masa tersebut. Lebih rincinya, gambar tentang bangunan peninggalan berjumlah tujuh belas kemudian gambar tentang

${ }^{28}$ Mulyasa, 22.

${ }^{29}$ Tim Penyusun, Standar Kompetensi Nasional (Jakarta: Departemen Pendidikan Nasional, 2004), 75.

${ }^{30}$ Murodi, Sejarah Kebudayaan Islam I (Semarang: Karya Toha Putra, 2004), 125.

${ }^{31}$ Murodi, Sejarah Kebudayaan Islam II (Semarang: Karya Toha Putra, 2004), 86.

${ }^{32}$ Murodi, Sejarah Kebudayaan Islam III (Semarang: Karya Toha Putra, 2004), 96. 
tokoh berjumlah tujuh dan selebihnya bergambar peta peperangan dan gambar terjadinya perang tersebut.

Selanjutnya materi sejarah kebudayaan Islam mulai dari kelas I sampai dengan kelas III terdiri dari dua puluh dua bab. Dari bab tersebut, hampir delapan puluh persen memuat tentang strategi politik, militer dan kekuasaan, selebihnya tentang ilmu pengetahuan dan tekhnologi. Pada pengambilan tokoh sejarah dalam materi tersebut, semuanya menceritakan tokoh-tokoh sejarah yang berjenis kelamin laki-laki baik tokoh yang berkaitan dengan dunia politik dan militer maupun tokoh yang berkaitan dengan ilmu pengetahuan dan tekhnologi.

Selanjutnya pada sektor strategi penyebaran agama Islam dan pemerintahan daulah Islamiyah, sembilan puluh persen lebih menonjolkan intrik-intrik politik kekerasan dan permusuhan, misalnya peperangan, pembunuhan dan juga penipuan.

\section{Materi SKI MTs Perspektif Humanisme Pendidikan}

Pada penjelasan di atas telah penulis uraikan secara sederhana materi sejarah kebudayaan Islam di MTs dan teori pendidikan dan humanisme serta psikologi perkembangan anak sesuai dengan tema penulisan artikel ini. Dalam bab IV ini penulis akan mencoba melihat secara obyektif tentang hubungan antara materi sejarah kebudayaan Islam dengan psikologi perkembangan anak dengan kacamata humanisme pendidikan.

Memang akan kelihatan tidak gampang menganalisa dua hal tersebut yang kelihatannya sudah menjadi sebuah kebenaran yang mutlak. Namun ketika penulis mencermati dengan seksama kedua masalah tersebut, penulis menemukan beberapa ketimpangan-ketimpangan yang cukup signifikan dan menurut penulis hal itu akan berimbas pada kondisi psikologi anak didik.

Dalam buku materi sejarah kebudayaan Islam 1,2 dan 3 terbitan PT Toha Putra Semarang yang menggunakan Kurikulum Berbasis Kompetensi untuk tingkat Madrasah Tsanawiyah, penulis menemukan beberapa kejanggalan. Kejanggalan-kejanggalan tersebut tentunya dilihat dari beberapa aspek (konsep humanisme pendidikan). Untuk lebih jelasnya berikut penulis sampaikan kejanggalan tersebut menggunakan beberapa kacamata:

Pertama, materi SKI dilihat dari teori gender. Dari kutipan-kutipan materi sejarah kebudayaan Islam di atas bisa dengan jelas menemukan materi yang tidak berspektif gender. Hal ini bisa penulis buktikan dengan jumlah kutipan tokoh yang kesemuanya mengangkat laki-laki dalam sejarah kebudayaan Islam. Asumsinya dalam percaturan sejarah kebudayaan Islam perempuan tidak mempunyai peranan apapun. Bukankan dalam berbagai sejarah perempuan muslim juga ikut andil bagian dalam upaya penegakan panjipanji Islam ? Misalnya kita semua mengenal tokoh Rabiah Al Adawiyah seorang tokoh sufi perempuan yang tidak kalah dengan kaum laki-laki. ${ }^{33}$ Ataupun banyak juga tokoh-tokoh perempuan yang ikut dalam setiap perang sabil. Dari penuangan materi tersebut tentunya sangat tidak seimbang. Ketidakseimbangan jumlah ini dapat menimbulkan ketidakadilan gender yang berimbas pada stigma marginalisasi terhadap penokohan perempuan.

\footnotetext{
${ }^{33}$ Husain, Islam Agama Ramah Perempuan (Bandung: Fahmina Institute, 2003), 71.
} 
92 Humanisme Pendidikan .....

Telah dipaparkan sebelumnya marginalisasi terhadap perempuan dapat mengakibatkan pemiskinan karakter jenis kelamin perempuan. Pemiskinan akan menimbulkan kesan bahwa perempuan memiliki peran yang tidak penting dalam kehidupan. Dalam kasus seperti ini, Mansour Fakih mengistilahkan dengan bahasa adanya sub ordinasi perempuan.

Selain adanya peminggiran tokoh perempuan dalam perhelataan sejarah kebudayaan Islam, peniadaan atau penghilangan tokoh perempuan juga mengesankan bahwa peran laki-laki ini seakan-akan adalah baik dan menyematkan label bahwa perempuan adalah makhluk yang berlabel negatif (stereotipe). ${ }^{34}$

Konsep humanisme pendidikan tidak membenarkan praktik-praktik upaya penghilangan peran perempuan dalam sejarah kebudayaan Islam. Pengertian semacam ini akan masuk dalam memori anak yang pada akhirnya tertanam pengetahuan bahwa perempuan harus selalu berada pada ranah domestik karena telah terbukti dalam sejarah perempuan tidak berperan apapun dan pekerjaan publik adalah hak mutlak bagi laki-laki untuk mengerjakannya.

Pewilayahan sektor pekerjaan (baca : domestik dan publik) tidak akan menjadi persoalan yang berarti ketika dua jenis pekerjaan itu mendapat pengakuan yang sama bahwa keduannya adalah jenis pekerjaan. Namun akan muncul permasalahan jika keduanya dibedakan menurut jumlah penghasilan yang diterimanya. Ada anggapan berperan di wilayah domestik yang notabene tidak menghasilkan upah adalah bukan melakukan pekerjaan. Alhasil perempuan sering dilabelkan sebagai pelengkap kehidupan dan dalam setiap pengambilan keputusan dalam rumah tangga sering di dominasi oleh lakilaki. Semua ini lantaran budaya yang berkembang bahwa perempuan mempunyai sifat dasar feminine sehingga peran-peran kelembutan dan ketelatenan serta tidak butuh rasio melekat pada diri perempuan.

Dalam wujud gambar, banyak pula gambar yang di dominasi kaum laki-laki. Tak heran jika kemudian bagi para feminis liberal maupun radikal bahkan sosialis menjadikan persoalan ini sebagai dasar adanya ketidakadilan jenis kelamin yang selanjutnya harus diperjuangkan kebebasannya.

Kedua, Materi SKI dilihat dari teori pembebasan. Dalam ranah pembebasan ini tentunya lembaga pendidikan perlu memberikan konsepsi materi yang memiliki kesinambungan antara keinginan peserta didik dan mengusahakan sebuah konsep kurikulum pendidikan yang bisa mewadahi semua karakter masing-masing siswa. Selama ini kita bisa melihat bahwa masih terjadi banyak ketimpangan materi yang disampaikan dalam berbagai materi ajar, baik berupa materi dalam bentuk gambar maupun dalam bentuk tulisan.

Menurut konsep humanisme pendidikan penindasan, ketertinggalan dan kebodohan kaum manusia adalah kesalahan dari sistem pendidikan yang masih bersifat eksklusif. ${ }^{35}$ Untuk itu konsep humanisme pendidikan tetap konsen pada persoalan

\footnotetext{
${ }^{34}$ Fakih, Analisis Gender \& Transformasi Sosial, 16.

${ }^{35}$ Ben Agger, Teori Sosial Kritis (Yogyakarta: Kreasi Wacana, 2003), 63.
} 
bagaimana isu-isu kemanusiaan yang bersifat inklusif benar-benar dapat terwujud dalam lingkup pendidikan.

Berdasarkan teori pembebasan pembentukan karakter masing-masing manusia dimulai dari kebebasan berfikir kritis terhadap realitas wacana yang berkembang. Tak bisa kita nafikan bahwa dorongan dari luar sangat berpengaruh dalam perkembangan psikologi manusia sehingga proses pencitraan diri seseorang yang merupakan ending dari persoalan krusial dalam konteks kekinian menjadi terhambat akibat kesalahan kurikulum pendidikan.

Kemudian yang menjadi masalah lanjutan adalah penerapan kurikulum yang masih sarat dengan kepentingan politis, beberapa buku rujukan masih mengedepankan upaya pembunuhan karakter terhadap beberapa sosok dan juga tokoh-tokoh yang tertuang dalam materi. $^{36}$

Inilah yang dimaksud dengan teori pembebasan ala konsep humanisme pendidikan dimana seorang peserta didik membutuhkan sebuah perlakuan yang layak sesuai dengan kodrat mereka sebagai manusia.

Lebih tegas lagi bahwa pendidikan harus bersifat netral dan tidak ada nuansanuansa penggirangan terhadap suatu opini yang berkembang sejalan dengan perkembangan peradaban umat manusia seperti temuan beberapa penelitian yang masih sarat dengan nilainilai kekerasan, peminggiran seksis, fundamentalime dan juga nuansa-nuansa politik-politik pendidikan lainnya.

Khusus dalam materi sejarah kebudayaan Islam nuansa-nuansa pembunuhan karakter masih nampak dengan jelas di mana tokoh-tokoh dalam sejarah kebudayaan Islam berusaha dihilangkan karakternya. Selain penghilangan karakter tokoh, dalam materi sejarah kebudayaan Islam juga ada nuansa penggiringan untuk membela terhadap satu tokoh dan menyalahkan tokoh yang lain (like and dis like). Misalnya tokoh Muawiyah merupakan tokoh yang melakukan kudeta terhadap pemerintahan Ali Bin Abi Tholib.

Di samping ada nuansa suka dan tidak suka terhadap tokoh, dalam materi tersebut terdapat usaha penggiringan siswa untuk menggeluti dunia politik. Hal ini dapat kita lihat dari data yang menyebutkan bahwa semua materi yang dikemas adalah meteri tentang dunia politik dan kekuasaan, misalnya bagaimana proses perpindahan kekuasaan dari bani Umayah ke Abasiyah danatau perpindahan dari bani Abasiyah ke Ayyubiyah, padahal penulis menilai masih banyak sejarah kebudayaan Islam yang berasal dari selain materi politik. Kalaupun toh ada hanya beberapa bagian dan diceritakan dalam sub bab yang singkat.

Jadi harapan yang muncul dari praktik pembebasan pendidikan ini adalah berusaha bersikap obyektif terhadap ilmu pengetahuan yang selanjutnya peserta didik akan memilih sendiri atas keberlangsungan hidup selanjutnya.

Ketiga, Materi SKI dilihat dari teori psikologi. Setelah penulis mencoba menganalisa dan memaparkan dengan uraian tadi, jelas sekali bahwa dalam materi sejarah kebudayaan Islam yang diterapkan dalam kurikulum madrasah tsanawiyah masih terdapat bias gender dan sangat bertentangan dengan konsep pendidikan androgene karena praktikpraktik tranformasi keilmuan masih mempunyai unsur-unsur marginalisasi dan pelabelan

\footnotetext{
${ }^{36}$ Freire, Poltik Pendidikan, 73.
} 
94 Humanisme Pendidikan .....

negatif terhadap peran perempuan dengan dibuktikan adanya kalkulasi contoh materi yang tidak berimbang. Kemudian juga dalam materi tersebut juga ada nuansa politisasi pendidikan.

Lebih jauh penulis ungkapkan bahwa dari kaidah-kaidah pembelajaran agama telah jelas diterangkan bahwa Islam tidak mengenal istilah pembedaan berdasarkan jenis kelamin (laki-laki dan perempuan) yang membedakan hanyalah tingkat keimanan seseorang semata, sehingga ilmu sejarah penciptaan manusia perlu ditafsirkan ulang kebenarannya.

Bila di lihat dari kaca mata psikologi, materi yang bias gender dan juga ada upaya politisi pendidikan akan sangat berpengaruh pada kondisi perkembangan siswa. ${ }^{37}$. Taruhlah ketika yang dituangkan dalam materi sejarah kebudayaan Islam adalah hal-hal yang berbau kekerasan maka akan sangat mungkin siswa yang sedang berada dalam masa pencarian dan juga masa imitasi bertindak dengan cara-cara kekerasan untuk membela kemurnian dan kesucian Islam (baca : mencoba menjadi teroris).

Lebih parah lagi bila cara berpolitik yang disebutkan dalam materi tersebut diejawantahkan oleh anak dalam kehidupan sehari-hari. Beberapa kasus yang lalu telah disebutkan dalam televisi bahwa banyak anak yang melakukan adegan seperti halnya tayangan smack down yang beimbas pada cideranya beberapa anak tersebut. Ironisnya hal tersebut juga dilakukan oleh anak berusia belasan tahun.

Bukankah kita semuanya tahu bahwa usia anak remja masih sangat labil dalam menentukan arah pijakan hidup dan juga masih berusaha mencari jati dirinya? sehingga semua yang anak dapat baik dari bacaan, tayangan televisi maupun tutur kata manusia yang lainnya dapat diejawantahkan dalam kehidupan sehari-hari.

Kesimpulannya bahwa materi sejarah kebudayaan Islam di MTs belum mengacu pada ilmu psikologi perkembangan anak yang sedang berada pada masa imitasi. Bukan tidak mungkin dengan penggunaan materi sejarah kebudayaan Islam yang kurang humanis (menonjolkan unsur-unsur kekerasan dan intrik akan menelorkan pemuda-pemuda yang anarkhis dengan menggunakan dalih kebenaran dan teladan dari agama Islam.

\section{Pengaruh Materi Terhadap Peserta Didik}

Dari pemaparan di atas ternyata dalam materi SKI masih terdapat ketimpanganketimpangan yang ditimbulkan dari adanya perbedaan gender, semangat pembebasan dan psikologi anak. Berikut penyusun paparkan pengaruh materi terhadap anak didik:

Pertama, Aspek Kognitif. Untuk dapat memahami substansi ilmu pengetahuan, aspek kognitif (aspek kecerdasan) merupakan landasan awal guna mencapai tujuan ilmu. Dapat berfikir secara luas, memahami informasi yang disampaikan baik secara lisan maupun terrtulis dan juga membuat inovasi-inovasi baru menjadi bagian dari kerja-kerja domestik otak. Guna menunjang peningkatan skill berfikir peserta didik tersebut maka dilengkapi dengan komponen proses pendidikan seperti kurikulum, media pembelajaran, buku pelajaran serta guru. Komponen-komponen tersebut merupakan faktor yang cukup dominan dalam pencapaian tujuan pendidikan.

${ }^{37}$ Malik Fajar, Visi Pembaharuan Pendidikan Islam (Jakarta: LP3NI, 1998), 192. 
Telah disampaikan bahwa buku materi sebagai salah satu yang menunjang keberhasilan pendidikan maka ketika dalam buku materi tersebut ada pokok bahasan yang bias gender secara tidak langsung akan berimbas pada pelanggenagan budaya-budaya patriakhi yang terbukti selama ini membelenggu perempuan-perempuan Indonesia dan juga ada upaya pencetakan siswa untuk menjadi seorang politikus yang menghalalkan segala cara (Politisasi Pendidikan). Logika yang dipakai pada anak usia anak sekolah SMP (belasan tahun), kondisi pola pikir masih banyak dipengaruhi pola-pola imitasi. Sebagai makhluk yang baru mencari sebuah kebenaran maka apapun yang ia lihat dan dengarkan akan dimasukkan dalam memori otaknya. Tak terkecuali dengan kasus bias gender dan politisasi pendidikan dalam buku pelajaran tersebut. Jadi dalam aspek kognitif keadaan materi yang salah akan sangat berpengaruh.

Terkondisikannya pola pikir anak dengan ungkapan "ternyata peran laki-laki adalah yang terhebat dan peran perempuan hanya pada wilayah domestik semata", "laki-laki bertindak sebagai pemimpin keluarga dan perempuan berperan sebagai penjaga rumah" dan "laki-laki mempunyai sifat maskulin (punya kekuatan) dan perempuan mempunyai sifat feminine (mempunyai sifat lembut)" menjadi mainstreem tersendiri. Selain itu bahwa hidup ini akan menarik jika kita terjun langsung pada dunia politik praktis menjadi sebuah dewa yang selalu menggelayuti setiap benak penerus bangsa ini.

Kedua, Aspek Emosi. Yang dimaksud dengan emosi disini adalah bagaimana seorang siswa atau siswi dapat menolak atau menerima sesuatu yang diberikan oleh orang lain, misalnya kasus yang terjadi ketika seorang anak laki-laki enggan diberikan sebuah boneka yang lucu dan sebaliknya seorang anak perempuan malu jika menggunakan mobil-mobilan sebagai mainannya.

Dalam konteks materi sejarah kebudayaan Islam anggapan bahwa seorang anak laki-laki adalah lebih kuat dibanding perempuan dan anak perempuan mempunyai sifat pemalu sehingga anak laki-laki akan selalu berusaha menunjukkan keperkasaannya dan sebaliknya karena perempuan tidak masuk dalam daftar sejarah kebudayaan Islam maka akan menghantarkan pada pola pikir perempuan tidaka akan berjuang untuk menegakkan agama Allah karena dalam sejarahpun peran perempuan tidak ada tidak di syariatkan.

Kasus seperti ini adalah salah satu imbas dari penerapan kurikulum pendidikan yang masih dirasa bias gender. Kejadian-kejadian ini akan berkembang menjadi sebuah doktrin yang paling benar dan akan terus berkembang dan akhirnya keberadaan kaum perempuan Indonesia tak tahu sesungguhnya jati dirinya bila tidak segera dibenahi.

Inilah dampak terburuk dari kurikulum yang bias gender yang mana siswa akan mengalami sikap-sikap phobi dalam kancah pesaingan percaturan dunia yang semakin menglobal.

Kemudian buku sejarah kebudayaan Islam yang lebih menonjolkan pada sisi politiknya, juga akan berpengaruh pada pencapaian cita-cita seorang siswa untuk berusaha menjadi seorang politikus atau menjadi agamawan yang radikal.

Ketiga, Aspek Sosial. Kecenderungan anak laki-laki yang termotivasi dengan propaganda sebagai makhluk yang kuat (maskulin) telah mengajarkan pada siswa sebuah keinginan yang kuat untuk bisa bergerak secara leluasa dan bebas adalah salah satu contoh imbas penggunaan materi yang bias gender sedangkan dengan stigma makhluk yang lembut 
96 Humanisme Pendidikan .....

(feminine) melahirkan anak perempuan yang lebih cenderung diam dan lamban dalam bergerak serta gampang berputus asa.

Kemudian siswa akan cenderung menciptakan sebuah dikotomi baru antar umat manusia ketika manusia lain tedak sepaham dengan paradigma yang mereka bangsun sendiri. Ringkasnya bahwa keyakinannyalah yang paling benar dan orang lain salah sehingga ornag lain patutu untuk dimusuhi.

Perbedaan-perbedaan ini yang menjadi bahan refleksi bersama bahwa penggunaan materi yang masih bias gender akan mengakibatkan sikap dan perilaku seperti yang penulis utarakan diatas.

\section{Kesimpulan}

Dari hasil pemaparan dan analisa dalam artikel ini, penulis dapat menghasilkan beberapa item kesimpulan yaitu:

Pertama, bahwa menggagas pola kehidupan pendidikan manusia sebagai subyek dunia tidak akan pernah selesai. Khusus untuk bahan pendidikan sejarah kebudayaan islam yang berlaku di Madrasah Tsanawiyah, penulis masih banyak menemukan materi yang menurut konsep pendidikan kekinian (humanisme pendidikan) kurang mengacu pada konsep ini. Hal ini terwakili pada temuan tentang sample-sample (baik itu materi tertulis maupun dalam bentuk gambar) yang masih cenderung merugikan salah satu jenis kelamin yaitu jenis kelamin perempuan dan juga ada upaya penggiringan siswa untuk menjadi seorang politikus serta mengajarkan siswa pada budaya kekerasan. Dampak dari penggunaan sample tersebut akan sangat membahayakan sisi psikologi pada anak didik. Ketidakadilan gender, politisasi pendidikan dan violence cultur akan terpupuk secara subur dikalangan masyarakat luas.

Kedua, membudayanya budaya penerapan agama kekerasan membuat para pemerhati pendidikan merasa gerah dan membuat berbagai terobosan sebagai sarana protes terhadap bangunan budaya-budaya yang menunjukkan status quo ini. Upaya yang dilakukan guna menghindarkan dari praktik-praktik ketidakadilan adalah melalui perubahan dunia pendidikan. Adalah gambaran tentang konsep humanisme pendidikan yaitu pendidikan yang memuat unsur kesetaraan, dan pembebasan menjadi hal yang mutlak diperlukan dalam rangka mengkikis habis budaya-budaya dewa kekerasan. Hal ini berangkat dari asumsi peserta didik adalah salah satu generasi mendatang yang akan memimpin dan membangun roda kehidupan baik itu di sektor politik, agama ataupun sektor kemasyarakatan yang lain.

\section{Daftar Pustaka}

Agger, Ben. Teori Sosial Kritis. Yogyakarta: Kreasi Wacana, 2003.

Ahmad, Farida. "Wacana Gender Bukan Hanya Milik Perempuan," 17 September 2004.

Ardi Widodo, Sembodo. Kajian Filosofis Pendidikan Barat dan Islam. Jakarta: Nimas Multima, 2003.

Arikunto, Suharsimi. Prosedur Penelitian Suatu Pendekatan Praktik. Jakarta: Rineke Cipta, 2002. 
Baedowi, Ahmad. Tafsir Feminis. Bandung: Nuansa, 2005.

Baidan, Nasharuddin. Tafsir Bi Al Ra'yi. Yogyakarta: Pustaka Pelajar, 1999.

Depag RI. Al Qur'an dan Terjemahannya. Bandung: Gema Risalah, 1992.

Fajar, Malik. Visi Pembaharuan Pendidikan Islam. Jakarta: LP3NI, 1998.

Fakih, Mansur. Analisis Gender \& Transformasi Sosial. Yogyakarta: Pustaka Pelajar, 2001.

Freire, Paulo. Menjadi Guru Yang Merdeka. Yogyakarta: LKis, 2001.

—. Poltik Pendidikan. Yogyakarta: Pustaka Pelajar, 2002.

Husain. Islam Agama Ramah Perempuan. Bandung: Fahmina Institute, 2003.

Ismail, Nurjanah. Perempuan Dalam Pasungan. Yogyakarta: LKis, 2003.

Kusti'ah, dan Anny Aisah. Belajar Gender Analisis Mengurai Ketimpangan Gender dalam Realitas Masyarakat. Semarang: JGJ PMII Jateng, 2005.

Moleong, Lexy J. Metodologi Penelitian Kualitatif. Bandung: Remaja Rosda Karya, 2007.

Mulyasa. Kurikulum Berbasis Kompetensi, Konsep, Karakteristik Implementasi dan Inovasi. Bandung: Remaha Rosdakarya, 2004.

Murodi. Sejarah Kebudayaan Islam I. Semarang: Karya Toha Putra, 2004.

- Sejarah Kebudayaan Islam II. Semarang: Karya Toha Putra, 2004.

—. Sejarah Kebudayaan Islam III. Semarang: Karya Toha Putra, 2004.

Muthali'in, Achmad. Bias Gender dalam Pendidikan. Surakarta: Muhammadiyah University Perss, 2001.

Partanto, Pius A, dan M Dahlan Al Barry. Kamus Ilmiah Populer. Surabaya: Arkola, 1994.

Penyusun, Tim. Kurikulum Madrasah Tsanawiyah (standar Kompetensi). Jakarta: Departemen Pendidikan Nasional, 2004.

—. Standar Kompetensi Nasional. Jakarta: Departemen Pendidikan Nasional, 2004.

Sarifatun, Elis. "Pendidikan Androgene; Sebuah Refleksi Terhadap Materi Pelajaran, Temanggung," 2005.

Syalabi, A. Sejarah dan Kebudayaan Islam. Jakarta: Pustaka Alhusna, 1990.

Toha, Chabib. Reformulasi Filsafat Pendidikan Islam. Yogyakarta: Pustaka Pelajar, 1996.

Yusuf, Syamsu. Psikologi Perkembangan Anak dan Remaja. Bandung: Remaja Rosda Karya, 2004. 